\title{
Türk Romanında Salgın Hastalıklar
}

\author{
HAYRUNISA TOPÇU* \\ nisa@hacettepe.edu.tr \\ ORCID ID: 0000-0003-2624-5148
}

\begin{abstract}
Öz: Salgın hastalıkların geçmişi, insanlığın ortaya çıkışı kadar eskidir. Toplu ölümler, insanların hastalık karşısındaki çaresizlikleri, ıstırapları edebiyat açısından zengin bir malzeme kaynağıdır. Türk Romanında Salgin Hastalıklar isimli bu çalışmada, Tanzimat'tan günümüze romanlarda salgın hastalıkları konu eden eserler tespit edilmeye çalışmıştır. Tespit edilen eserler içerisinden kronolojik sıralamayla Felâtun Bey ile Râkım Efendi, Taaşşuk-ı Talât ve Fitnat, Aşk-ı Memnu, Hakka Siğındık, Yeşil Gece, Salgın, Hüyükteki Nar Ağacı, 30 Şubat Bir Gülme Salginın Romanı, Sicak Kafa, Y, Hastalı, Merakl Adamın On Günü isimli romanlar değerlendirmek üzere seçilmiştir. Bu romanları değerlendirmekteki amaç salgin temasinın romanlardaki değişimini gözlemlemektir. Nitekim Tanzimat ve Servet-i Fünûn romanlarında verem hastalı̆̆ öne çıkarken, II. Meşrutiyet ve Cumhuriyet Dönemi romanlarında salgin, toplumsal sorunlarm tespit edilmesinde bir araç halini alır. 2000'li yıllarda kaleme alinan romanlarda ise salgin teması distopik/fantastik unsurlar etrafinda şekillenir.
\end{abstract}

Anahtar kelimeler: Hastalı, Salgın, Türk romanı, Fantastik roman, Distopik roman

\section{Giriş: Edebiyat ve Salgın Hastalıklar}

Hastalık, en basit tabirle, standart işleyiş içerisinde ilerleyen fiziksel ve ruhsal sistemde görülen aksaklık sonucu ortaya çıkan durumdur. Tahmin edileceği üzere hastalıkların onlarca farklı nedeni olabilir. Tıp, gerek hastalıkların nedenlerini ortalığı ortadan kaldırmak, gerekse hastalıklara yakalanmayı önlemek adına birçok farklı disiplinle işbirliğini halinde çalışmalarını sürdürür. Hastalığı edebiyat araştırmacıları için çalışma konusu haline getirense yaratım süreci ile kurduğu ilişki ve bireysel, toplumsal düzlemdeki yansımalarıdır.

Sanat - onun özelinde edebiyat - yaşama ve evrene dair soru / sorunların itkisiyle ortaya çıkar. Yani insanın arayışından, tamamlanmamışlığından, tereddütlerinden ve varoluşunu bunların içinde sürdürerek dünyayı anlamlandırma çabasından beslenir. Tamamını sisteme dahil olmuş ve hayatı kabulleniş içerisinde yaşayan insanların oluşturduğu bir dünyada sanatın varlığ 1 da tartışmalı olacaktır. İşte bu noktada hastalık hem sanatçıya hem de okura yeni bir pencere açar: Ruhsal ve fiziksel

* Dr. Öğr. Üyesi, Hacettepe Üniversitesi, Edebiyat Fakültesi, Türk Dili ve Edebiyatı Bölümü. 
ıstırabın gerisinden yaşamı kavrama çabası. Cem Uraldı hastalığın edebiyatta açtı̆̆ 1 pencereleri şu cümlelerle özetler: "Bir tema olarak hastalık ürettiği acı, 1stırap, düşkünlük, yalnızlık, hayal kırıklığı, ümit, ümitsizlik, merhamet gibi duygularla alabildiğine zengin bir yazın alanı oluşturur. Kurgusal dünyaları ete kemiğe büründüren, sahici kılan bir atmosfer oluşturmaya katkı sunar. Kahramanların deneyimledikleri maddi olguların yanı sıra ruhsal hissedişlerine dair betimlemeler yapabilmeye de olanak sağlar."' Yani edebiyatta hastalık algısı, hem gerçekliğe hizmet eder hem de insanın acizliği ve varoluşundaki açmazların sorgulanacağı zengin bir alan sağlar.

Selçuk Çıkla, edebiyat eserlerine konu olan hastalıkları bireysel ve toplumsal olmak üzere ikiye ayır. Bireysel hastalıkları üç grupta toplar. İlk gruptaki hastalıklar; fiziksel rahatsızlıklar, vehim, takıntı, histeri gibi ruhsal rahatsızlıklar, huy ve inanç dünyasıyla ilgili olan kibir, hayâsızlık, riya, yalan gibi manevi rahatsızlıklar başlıkları altında kendi aralarında üçe ayrılırlar. İkinci gruptaki toplumsal hastalıklar bağlamında ise haset, entrikacılık, tamahkârlık, adam kayırma, hurafecilik, tefecilik gibi davranış biçimlerinden bahsedilebilir. Bu gruptaki hastalıklar, toplumda çürüme ve yozlaşma yaratırlar. ${ }^{2}$ Bu çalışmanın konusunu oluşturan salgın hastalıklar ise fiziksel rahatsızlıklar kapsamındadır. Salgınları ortaya çıkışları ve ilerleme süreçleri itibarıyla fiziksel hastalık bağlamında değerlendirmek mümkün olsa da bıraktıkları etkiyi fiziksel, toplumsal ve ruhsal düzlemde incelemek gerekir.

Salgınların toplumda bıraktıkları etkiler benzer özellikler gösterir. Salgının görülme süresine bağlı olarak da bu etkilerin kalıcılığı artabilir. İşte edebiyat bu noktada devreye girerek salgın hastalıkla karşı karşıya kalan insanın ölüm korkusunu, acizliğini, - diğer hastalıklardan farklı olarak - hastalığı başkalarına bulaştırma endişesini kendine malzeme eder. Salgınları ölümcül olan diğer hastalıklardan ayıran temel özellik bulaş riski taşımalarıdır. Çünkü bu riskin büyüklügü veya küçüklügü yeni bir yaşam algısının doğmasına neden olabilir. Salgın hastalıkların birçoğunda temel korunma yöntemlerinden kabul edilen izolasyon ve sınırlı temas, sosyal bir canlı olan insanı korunaklı mekânlara hapseder. Ne var ki bu durum yalnızca fiziksel bir hapsoluşu değil, yeni bir yaşam biçimini ve ruhsal buhranı da beraberinde getirir. Edebiyat bu sorgulama ve anlamlandırma sürecinin zaman zaman destekçisi zaman da aynası işlevini görür. Salgını işleyen edebiyat eserlerine hemen her toplumda rastlamak mümkündür. Bunları hatırlayacak olursak ilk olarak İtalyan edebiyatçı Giovanni Boccacio'nun veba salgınında kaleme aldığı eseri Decameron Hikâyeleri'nden bahsedilebilir. Bunu Gabriel Garcia Marquez'in Kolera Günlerinde Aşk, Daniel Defoe’nin Veba Yılı Günlüğ̈̈̈, Jose Saramago'nun Körlük, Albert Camus ve Michael Grant'in Veba, Lack London'ın Kızıl Veba ve Erin Bowman'in Salgin adlı eserleri izler. ${ }^{3}$ Roman Kahramanları isimli derginin salgın edebiyatı konulu dosyasinda bu listeye Mary Shelley'nin Son Insan, ${ }^{4}$ Alessandro Manzoni'nin

${ }^{1}$ Cem Uraldı, "Edebiyat ve Sağlık”, Hece (Edebiyat ve Hastalık Dosyası), 225 (2015), s.101.

${ }^{2}$ Selçuk Çıkla, Edebiyat ve Hastalık, İstanbul: Kapı Yayınları, 2016, s.17.

${ }^{3}$ Faik Bulut, "Salgın ve Hastalıkların Edebiyat ve Sanata Yansımış Hikayeleri”, Indepent Türkçe, erişim 26 Ocak, 2021, https://www.indyturk.com/node/162101/türkiyeden-sesler/salgın-hastalıkların-edebiyat-vesanata-yansımış-hikayeleri.

${ }^{4}$ İsmail Cem Doğru, "Shelley'nin Kapanış Teorisi: Son İnsan”, Roman Kahramanları (Salgın Edebiyatı Dosyas1), 44 (2020), s.19. 
Nişanlılar, ${ }^{5}$ Edgar Allen Poe'nun Kızıl Ölümün Maskesi Üzerine, ${ }^{6}$ Thomas Mann'ın Venedik'te Ölüm, ${ }^{7}$ Katherine Anne Porter'in Soluk At, Soluk Binici, ${ }^{8}$ Robin Cook'un Salgin, ${ }^{9}$ Vlademir Sorokin'in Tipi, ${ }^{10}$ Philip Roth'un Nemesis, ${ }^{11}$ Dan Brown'un Cehennem, ${ }^{12}$ Yuri Herrera'nın Bedenlerin Göçü ${ }^{13}$ isimli eserleri de eklenir. Sıralanan bu eserlerde salgın hastalıklar insanların bireysel yaşamlarında yaptığı ruhsal, fiziksel tahribat ve toplumların karşı karşıya kaldıkları yeni yaşam biçimleri bağlamında ele alınmışlardır.

Türk romanında salgını konu alan eserlere bakıldığında ise nicelik olarak olmasa da nitelik anlamında zenginlik ve dönüşümün yaşandığı görülür. Modern Türk romanının doğuşuna kaynaklık eden Tanzimat Dönemi'nde salgın hastalıklar maddi olarak yoksulluğun, duygusal olaraksa aşkın ve melankolinin simgesi iken, II. Meşrutiyet Dönemi'nde ve cumhuriyetin ilk yıllarında gerçekçi ve eleştirel bir tavırla ele alınır. Sosyal adaletsizlik, cehalet, bürokrasinin yarattığı sıkıntılar bağlamlarında işlenir. Günümüze yaklaştıkça ise salgın hastalıkların konu edildiği eserlere distopik ve fantastik unsurlar egemen olur. Bu temaların etraflı şekilde analiz edilebilmesi ve dönüşüm süreçlerinin incelenebilmesi için tarihteki salgın hastalıklara göz atmak faydalı olacaktır.

2002 yılında başlayan SARS salgını 2003 yılında Haziran ayında sona erer. Damlacık yolu ile insandan insana bulaşan solunum yolu hastalığıdır. 2012'de Arap yarımadası, 2015'te Kore Cumhuriyeti'nde görülen MERS'in insandan insana yakın temas yoluyla geçtiği tespit edilmiştir. Ölümcül bir hastalık olan Ebola virüsü, hastalığı kapmış canlı / ölü insan veya hayvandan bulaşabilir. 18. ve 19. yüzyıllarda Avrupa'da yaygın biçimde görülen sifiliz cinsel yolla bulan bir hastalıktır. Sivrisinekler aracılığıyla bulaşan sıtmayla ilgili kayıtlar M. Ö. 1500'lü yıllara dek uzanır. Gribe neden olan virüslerin sürekli mutasyon geçirmeleri sonucu tarihin çeşitli dönemlerinde grip salgınları yaşanmıştır. Grip salgınlarının en etkilisi 1918-1919 yılları arasında yaşanan İspanyol gribidir. Milyonlarca kişinin ölümüne neden olmuştur. Bunun ardından 1956-1958 yılları arasında Asya gribi, 1997’de Hong Kong'ta ise HN51 salgını görülmüştür. Birçok edebiyat eserine de konu olan veba salgınları tarihte 541,1347, 1894'te olmak üzere üç defa görülmüş ve milyonlarca insanın ölümüne neden olmuştur. 1950'li yıllardan itibaren koruyucu hekimlik ve antibiyotik kullanımıyla birlikte salgınlar engellenmiştir. Su ve mikroplu gıdalar

\footnotetext{
${ }^{5}$ Zeynep Yenen, “Trump ve Bolsonaro Manzoni Okusaydı”, Roman Kahramanları (Salgın Edebiyatı Dosyası), 44 (2020), s.27.

${ }^{6}$ Erkan Karakiraz, "Edgar Allen Poe’nun Maskesi - Kızıl Ölümün Maskesi Üzerine”, Roman Kahramanları (Salgın Edebiyatı Dosyası), 44 (2020), s.32.

${ }^{7}$ Medeni Yılmaz, “Venedik’te Ölüm: Şimdi Ben Gidiyorum, Phaidros, Sen Burada Kal!”, Roman Kahramanları (Salgın Edebiyatı Dosyası), 44 (2020), s.35.

${ }^{8}$ John Domini, “Uyduruk Haberler, Aşırı Vatanseverlik ve Savaş: 1918'de Amerika”, çev. Altay Ömer Erdoğan, Roman Kahramanları (Salgın Edebiyatı Dosyası), 44 (2020), s.56

${ }^{9}$ Neslihan Yalman, “Koronovirüsten Öncesi - Romandan Güne Bakmak 'Salgın' Notları: İzmir, Türkiye 1 Haziran 2020”, Roman Kahramanları (Salgın Edebiyatı Dosyası), 44 (2020), s.93.

${ }^{10}$ Fatih Akça, "Çağdaş Bir Kış Masalı: Tipi”, Roman Kahramanları (Salgın Edebiyatı Dosyası), 44 (2020), s.127.

${ }^{11}$ Eda Demir, "Philip Roth'un Nemesis'inde Ayarı Bozuk Terazi ve İlahi Adalet", Roman Kahramanları (Salgın Edebiyatı Dosyas1), 44 (2020), s.131.

${ }^{12}$ Hüma Erk Görgülü, “Cehennem: Şimdi değilse, ne zaman?”, Roman Kahramanları (Salgın Edebiyatı Dosyasi), 44 (2020), s.136.

${ }^{13}$ Altay Ömer Erdoğan, "Korkunç Şeylerin Masumiyeti”, Roman Kahramanları (Salgın Edebiyatı Dosyası), 44 (2020), s.145.
} 
aracılığıyla bulaşan koleraya ait ilk salgın 1817 'de ortaya çıkmıştır. Daha sonra 1860'lara kadar Asya, Avrupa, Kuzey Amerika ve Afrika'yı etkileyen salgınlar görülmüştür. Salgınlara neden olan bir diğer hastalık lepradır. Sinirleri, deriyi, gözü, kemikleri, testisleri ve üst solunum yolunu etkileyen bir hastalık olan lepranın tedavisi 1980'lerden sonra etkili bir şekilde yapılmaya başlanır. Kirli içme suları ve pis yiyecekler aracılığ 1 ile bulaşan tifo dünyada her yıl 20 milyon insanın hastalanmasına neden olmaktadır. Kişinin bağışıklık sistemine saldıran bir virüs olan HIV/AİDS ilk kez 1976'da Kongo Demokratik Cumhuriyeti'nde tanımlanmıştır. Tarihte en fazla kayba neden olan hastalık olarak bilinen çiçek hastalığı, 300 ile 500 milyon arasında kişinin ölümüne neden olmuştur. Hastalığın geçmişinin Mısır'da firavunlar dönemine dek uzandığı tespit edilmiştir. Tifüse neden olan bakteri, enfekte olmuş bit, pire, kene, akarlar tarafından taşınır. 1. ve 2. Dünya savaşlarından sonra Anadolu'da, Avrupa'da, Kuzey Afrika'da salgınlara neden olmuştur. Geçmişi M.Ö 5. yüzyıla dek uzanan tüberküloz, halk arasında bilinen adıyla veremin Avrupa'da neden olduğu salgınlar 1600'lü yıllarda başlamıştır, yaklaşık 200 yıl devam etmiştir. 2020 yılında başlayan COVID-19 salgını ise halen devam etmektedir. ${ }^{14} \mathrm{Bu}$ hastalıklara ek olarak kızamık, trahom, difteri (kuşpalazı) ve frengiden de bahsedilmelidir. Kızamık 11. ve 12. yüzyıllarda büyük çaplı salgınlara neden olan bir çocukluk çağı hastalığıdır. Frenginin 1493'te Christoph Colomb ve beraberindeki denizciler tarafından Avrupa'ya taşındığı düşünülmektedir. Sonraki beş yüz yıl boyunca etkili olmuştur. ${ }^{15}$ Ayrıca 16. yüzyılda görülen dizanteri ve 21. yüzyılda görülen domuz gribini de anımsamak gerekir. ${ }^{16}$ Görüldügü üzere salgın hastalıkların tarihi milattan önceki yıllara dek uzanmakta, birçoğu ise hâlen etkisini sürdürmektedir. Edebiyat eserlerinde ise bazı salgın hastalıkların diğerlerine göre daha fazla konu edildiği görülür.

Tanzimat'tan günümüze Türk romanında en sık karşılaşılan hastalık veremdir. Recaizâde Mahmut Ekrem'in Felâtun Bey ile Râkım Efendi'de, Şemsettin Sami'nin Taaşşuk-ı Talat ve Fitnat' ta, Halit Ziya'nın Nemide, Aşk-ı Memnu, Mai ve Siyah romanlarında, Sami Paşazade'nin Sergüzeşti'nde, Ahmet Hamdi Tanpınar'ın Huzur'unda, Kerime Nadir'in birçok romanında veremli kahraman veya kahramanlar vardır. ${ }^{17}$ Veremin edebiyat eserlerine sıklıkla konu edilmesi bu alanda yapılan akademik çalışmaları da artırmıştır. Yavuz Selim Uğurlu Türk Romanında Verem Üzerine Bir Inceleme adlı çalışmasında bu listeye yeni isimler ekler. Verem, Ahmet Mithat Efendi ve Fatma Aliye Hanım'ın birlikte yazdıkları Hayâl ve Hakikât, Halide Edip Adıvar'ın Vurun Kahpeye, Ahmet Hamdi Tanpınar'ın Aydaki Kadın, Sabahattin Ali’nin İçimizdeki Şeytan, Peyami Safa'nın Dokuzuncu Hariciye Koğuşu, Kemâl Tâhir'in Karılar Koğuşu, Oğuz Atay'in Tutunamayanlar, Ayşe Kulin’in Fü-

\footnotetext{
${ }^{14}$ Hülya Parıldar, "Tarihte Bulaşıcı Hastalık Salgınları”, Tepecik Eğitim ve Araştırma Hastanesi Dergisi, 30 (2020), s.19-26.

${ }^{15}$ Namık Çeçen, “1933’ten Günümüze Lise Tarih Ders Kitaplarında Salgın Hastalıkların İşlenişine Genel Bir Bakış”, Milli Ĕgitim, 1 (2020), s.919-946.

${ }^{16}$ Firdevs Erdemir vd., "Yeni ve Yeniden Tanımlanan Enfeksiyonlar ve Enfeksiyon Kontrolü II 21. Yüzyılda Yeniden Tanımlanan Enfeksiyonlar ve Enfeksiyon Kontrolü”, Ege Üniversitesi Hemşirelik Yüksek Okulu Dergisi, 27/1 (2020), s.62.

${ }^{17}$ Çıkla, Edebiyat ve Hastalık, s.192-198.
} 
reya, İhsan Oktay Anar'ın Puslu Kitalar Atlası, Orhan Pamuk'un Kar adlı romanlarında da yer alır. ${ }^{18}$ Türk edebiyatının üretken yazarlarından Reşat Nuri Güntekin'in tüm romanlarında veremle birlikte çeşitli salgın hastalıklara rastlamak mümkündür. Bâki Asiltürk'ün bu konudaki çalışması yazarın romanlarını hastalıklar açısından ayrıntılı bir incelemeye tabi tutar. Buna göre Gizli El'de dizanteri ve İspanyol nezlesi, Çalıkuşu'nda difteri, tifo, verem, Damga' da verem, Dudaktan Kalbe'de tifo, Akşam Güneşìnde tifo, Bir Kadın Düşmani'nda tifo, Yeşil Gece'de çiçek hastalığı, verem, tifo, Acımak'ta verem, Kızılcık Dalları'nda verem ve çiçek hastalığı, Eski Hastalık'ta sıtma, tifüs, Ateş Gecesi'nde tifo, Değirmen'de sitma, Miskinler Tekkesi'nde sitma ve verem, Kavak Yelleri'nde sitma, veba, tifo, lepra işlenir. ${ }^{19}$ Ayrıca Reşat Nuri Güntekin'in Salgin isimli uzun hikâyesinde teşhis konulamamış bir salgın konu edilir. Romanlarda verem dışındaki hastalıklara örnek olarak şu eserler de verilebilir: Ahmet Mithat'ın Jön Türk eserinde kolera, Nabızâde Nazım'ın Karabibik'inde tifo, Halid Edip'in Mev'ud Hüküm'ünde frengi ve tifo, Peyami Safa'nın Sözde Kızları'nda frengi, Etem İzzet Benice'nin Beş Hasta Var'ında frengi yer alır. ${ }^{20}$ Bu eserlere Hüseyin Rahmi Gürpınar'ın Iffet eserinde işlenen difteri, Hakka Sığındık romanında geçen İspanyol gribi, Yaşar Kemal'in Hüyük'teki Nar A ̆gacı romanında yer alan sitma, İhsan Oktay Anar'ın Amat'ındaki veba hastalıkları da eklenebilir. Türk edebiyatında 2000'li yıllardan sonra kaleme alınan romanlara bakıldığında ise salgınların distopik ve fantastik unsurlar bağlamında işlendikleri görülür. Afşin Kum'un Sıcak Kafası'nda ARDS ismi verilen ve kişinin akıl yürütme mekanizmasını bozan bir hastalık, Cem Akaş'ın $Y$ isimli romanında erkeklere ait y kromozomunu yeryüzünden kaldıran bir salgın, Şebnem Şenyer'in 30 Şubat Bir Gülme Salgının Romanı'nda bulaşıcı bir gülme salgını, Onur Gürleyen'in Hastalık'ında kişilerin acı çekerek ölmesine neden olan bir hastalık anlatılır. Mehmet Eroğlu'nun 2021 yılında yayımlanan Meraklı Adamın On Günü adlı eserinde ise COVID-19 salgınına yer verilir.

Türk romanında salgın temasına yönelik yapılan taramalarda şüphesiz yeni eserler tespit edilecektir. Fakat yukarıda sıralanan eserlerden yola çıkılarak romanda salgın temasının işleniş biçimlerine dair bazı genellemeler yapmak mümkündür. Verem, daha önce de söylenildiği gibi hastalıkların içerisinde en yaygın biçimde işlenenidir. Bunun nedeni veremin tıbbî bir sorun olmasının ötesinde, yazarın ve eserlerdeki kahramanların kişisel özelliklerine, duygu dünyalarına, sosyal statülerine, yaşam koşullarına dair göndermeler barındırmasıdır. Yani veremin çoğunlukla içli, hassas, melankolik ve yoksullukla mücadele eden insanlarla özdeşleştirilmesidir. Bu durum, veremi diğer hastalıklardan farklı olarak sanat için daha zengin bir malzeme haline getirir. Verem dişındaki kolera, sıtma, dizanteri, tifüs, tifo, İspanyol gribi gibi salgın hastalıklar ise günlük hayatın yansımaları olarak eserlerde yer alırlar. Toplumsal sorunlara, yönetim mekanizmasına, cehalete işaret ederler. 2000'li yıllardan sonra kaleme alınan romanlarda ise yaşanmış, tanımlanmış bir salgın hastalık değil, salgın fikri konu edilir. Ülkeleri veya şehirleri kaosa sürükleyen salgınların ardından ortaya çıkan yaşam biçimleri, insan tipleri kurgulanır. $\mathrm{Bu}$

${ }^{18}$ Yavuz Selim Uğurlu, “Türk Romanında Verem Üzerine Bir İnceleme”, Sosyal Bilimler Enstitüsü Dergisi, 15 (2020), s.60.

${ }^{19}$ Bâki Asiltürk, Reşat Nuri Güntekin'in Romanlarında Hastalık, İstanbul: İkarus Yayınları, 2009, s.349-359.

${ }^{20}$ Çıkla, Edebiyat ve Hastalık, s.162-167. 
nedenle de bahsi geçen romanlarda distopik ve fanstastik unsurlar görülür. Hâlen devam eden COVİD-19'a yer veren yalnızca bir roman tespit edilmiştir. Bu romanda salgının günlük yaşamdaki yansımalarına yer verilir. Bu romanda salgına ilişkin hayalî veya fantastik unsurlar kullanılmaz, salgının etkilerinden gerçekçi bir bakış açısıyla bahsedilir. Çalışmanın sonraki bölümlerinde, bu çıkarımlar iki grupta değerlendirilecek ve seçilen romanlar üzerinden örneklendirilecektir.

\section{Gerçekçi ve Sembolik Bir Tutumla Değerlendirilen Salgın Hastalıklar}

Sanat, yaratıcılık ve yaşamın iç içe geçtiği bir alandır. Sanatçının ilhamı ve hayal gücünden beslendiği kadar toplumsal gerçeklerden de beslenir. Edebiyat da bu ilkeye uygun olarak insanların yaşantılarını kurgusal düzlemde yeniden yorumlayarak eserlerin meydana çıkmasına katkıda bulunur. Esra Kara sanat eserinin bir yönüyle bireysel, bir yönüyle toplumsal bir olgu olduğunu söyler. Sanatçının da yaşadığı evreni yorumladığını, eğer bu bağlamda bir romancıdan bahsediyorsak onun kendi görüşlerini eserine yansıttığını belirtir. ${ }^{21}$ Salgın hastalıklar da günlük yaşamın gerçeklerinden olarak edebiyat eserlerinde kendilerine yer bulurlar.

Verem, aşısının bulunduğu 1921 yılına kadar, dünyada milyonlarca kişinin ölümüne neden olmuş birçok edebiyat eserine de kaynaklık etmiştir. Veremin Türk edebiyatındaki yansımalarını ele alan çeşitli çalışmalar vardır. ${ }^{22}$ Bu çalışmada tekrara düşülmemesi açısından belirli örneklerle yetinilecektir. Verem dönemin şartlarına, günlük yaşama dair ayrıntılara ışık tutmakla birlikte kişilerin ruhsal özellikleri ile ilişkilendirilir. Bu nedenle iki açıdan ele alınması faydalı olacaktır.

Veremin romanlardaki tipik yansımalarından olan ve gerçekçi bir tutumla ele alınan yönü, yoksullukla, fiziksel koşulların yetersizliği ile ilişkilendirilmesidir. "Tüberküloz genellikle ince giysiler, cılız vücutlar, soğuk ısınmayan odalar, kötü sağlık koşulları ve yetersiz beslenmeden kaynaklan) bir yoksulluk ve mahrumiyet hastalığı olarak düşünülmüştür." ${ }^{23}$ Romanlarda Sontag'ın bu sözlerini destekleyecek birçok ifade vardır. Reşat Nuri'nin Yeşil Gece'sinde (1928) başkahraman Şahin Efendi medreseyi dolaşırken duyduğu ses üzerine şunları söyler: Şahin Efendi’nin kulağına yukarı pencerelerin birinden öksürüğe benzer hafif bir ses geldi. Genç muallim, titrek başını kaldırdı. Vaktiyle orada Ispartalı bir hasta çömez vardı. Aç açına çalışmaktan verem olmuştu. Hâlâ da eski bir kerevetin üstünde nöbetten titreye titreye çalışmaya devam ederdi." ${ }^{24}$ Veremin temel tedavilerinden biri ise hastanın iyi bakılacağı bir yer, yani tebdil-i mekândır. Sontag, verem hastalarına iyi geldiği düşünülen yerler olduğundan bahseder. Bunlar 19. yüzyılda İtalya, Akdeniz ve Güney Pasifik'teki adalar, 20. yüzyılda ise dağlar ve çöllerdir. Hastalar bu yerlerdeki sanatoryumlarda tecrit edilirler. Böylelikle seyahat özellikle 19. yüzyılda veremli

\footnotetext{
${ }^{21}$ Esra Kara, “Toplumsal Bir Olgu Olarak Sanat ve Edebiyat (Küçük Bir Sanatçının Omuzlarında Koca Bir Evren)”, Hece (Hayat Edebiyat Siyaset Özel Sayısı), 90/91/92 (2004), s.138-139.

${ }^{22}$ Ayrıntılı bilgi için şu çalışmalara bakılabilir: Melike Selcan Kalkan, "19. Yüzyıl Türk Edebiyatında Verem Hastalığı”, Yüksek Lisans Tezi, Marmara Üniversitesi, 2017., Sıddıka Dilek Yalçın Çelik, "Orhan Kemal'in Hikayelerinde İnce Hastalık: Verem ve Veremliler”, Doğumunun Yüzüncü Yılında Orhan Kemal Sempozyumu Kitabı, Ankara: Atatürk Kültür Merkezi Yayınları, 2016, s.211-230., Uğurlu, “Türk Romanında Verem Üzerine Bir İnceleme", s.57-69.

${ }^{23}$ Susan Sontag, Metafor Olarak Hastalık Aids ve Metaforları, çev. Osman Akınhay, İstanbul: Can Yayınları, 2020, s.25.

${ }^{24}$ Reşat Nuri Güntekin, Yeşil Gece, İstanbul: İnkılâp Yayınları, 2017.
} 
insanlar için bir yaşam biçimi haline gelir. ${ }^{25}$ Ahmet Mithat'in Felâtun Bey ile Râkım Efendi (1875) adlı romanında Râkım Efendi dadısına cariye satın alır. Cariyenin verem olduğunun anlaşılması üzerine getirilen hekim, cariyenin Kafkasya gibi soğuk bir memleketten İstanbul'a geldiği için iyileşeceğini söyler ve her sabah ballı süt içmesi tavsiyesinde bulunur. ${ }^{26} 19$. ve 20. yüzyıllarda Türk edebiyatında veremin işlendiği romanlara bakıldığında, hastalığın yetersiz beslenme, fiziksel olarak uygun olmayan koşullarda yaşanması gibi nedenlerle açıklanması gerçekçi yaklaşımı gösterir. Tedavi sürecinin sıcak ve nemli yerlerde iyi bir bakım altında devam ettirilmesi de hastanın yeni yaşam biçimini şekillendiren ölçütler olarak karşımıza çıkar. Fakat romanlarda veremi, nedenleri ve tedavi süreci ile ilgili biçimde ele alan yaklaşımlardan çok onu duygusal, psikolojik açılardan ele alan tavır daha yaygındır. Felâtun Bey ile Râkım Efendi'de İngiliz ailenin kızlarından Can, kendisine Türkçe dersleri veren Râkım Efendi'ye âşık olur. Bir süre sonra Râkım Efendi'ye duyduğu aşktan verem olur. ${ }^{27} \mathrm{Bu}$ örnekte veremin birçok tipik özelliği vardır. Hastanın iştahını azaltan ve zayıflayıp solmasına neden olan verem, Can’a da zayıf, narin bir görüntü katar. Ayrıca insanların vereme yakalanmalarının fiziksel nedenleri dışındaki temel nedeni karşılıksız aşk veya kavuşamamadır. Özellikle Tanzimat ve Servet-i Fünûn romanlarında kavuşamayan çiftlerden biri, aşkına karşılık bulamayan kadın / erkek hastalanarak yatağa düşer. Bu da veremin sembolik yönünü destekler. Verem salgın bir hastalık olmaktan çıkarak aşkın, kavuşamayan âşıkların sembolü haline gelir ve romantizmden beslenir. Şemsettin Sami'nin TaaşşukTalât ve Fitnat (1875) isimli romanında birbirlerine âşık iki genç Talât ve Fitnat'ın hikâyeleri anlatılır. Fitnat, Talât yerine zengin bir adamla evlendirilince üzüntüsünden zayıflar ve sararıp solar. İçinde bulunduğu durumu şu sözlerle anlatır: “Ah! Valideciğim! Benden ümidi kesin artık... Öleceğim... Öleceğim... Kan tükürüyorum... Verem oldum..." ${ }^{\prime 28}$ Verem sıradan insanların hastalığ değildir. Onun acı çekme üzerinden romantizmle kurduğu duygusal bağlar, veremi hassas, hüzünlü, duygusal açıdan derinliği olan hastalığı haline getirir. Örneğin Halit Ziya’nın Aşk$\iota$ Meтnu (1900) isimli romanında evin yardımcılarından Beşir veremden ölür. Onun Nihal'e duyduğu karşılıksız aşk, melankolik karakteriyle pekiştirilir. ${ }^{29} \mathrm{Ve}$ remli insanlar âdeta 19. yüzyılın hüzünden keyif alan marazî ruh haline tutkundurlar. Veremle bağdaştırılan ruhsal ıstırap romantizmin gölgesinde serpilip büyür. Eserlerde veremin bulaşıcı ve salgın hastalık olma özelliklerinden neredeyse hiç bahsedilmez. Veremli kişilerin tedavilerinin yapıldığg sanatoryumlar izolasyonla ilişkilendirilebilir veya hastaların eğer imkânları varsa evlerinde ayrı odada kalmaları ve kullandıkları eşyaların ayrılması bu bağlamda değerlendirilebilir. $\mathrm{Bu}$ tecrit edilme hali bireysel bir şekilde, yani romanların kahramanları ekseninde işlenir. Toplumsal bir kaygıya dönüştüğüne veya yeni bir yaşam şekli yarattığına tanık olunmaz. Yani verem Türk romanında toplumsal sonuçları olan değil, bireysel sonuçları olan, romantik bir hastalık olarak yer alır.

\footnotetext{
${ }^{25}$ Sontag, Metafor Olarak Hastalik Aids ve Metaforları, s.44.

${ }^{26}$ Ahmet Mithat Efendi, Felâtun Bey ile Râkım Efendi, haz., Mehmet Emin Agar, İstanbul: Enderun Kitabevi, 1994, s.13.

${ }^{27}$ Ahmet Mithat Efendi, Felâtun Bey ile Râkım Efendi, s.109-111.

${ }^{28}$ Şemsettin Sami, Taaşşuk-ı Talât ve Fitnat, haz., Özlem Nemutlu, İstanbul: Özgür Yayınları, 2015, s.142.

${ }^{29}$ Halit Ziya Uşaklıgil, Aşk-ı Memnu, haz., Muharrem Kaya, İstanbul: Özgür Yayınları, 2015.
} 
Romanlarda verem dışında frengi, tifüs, tifo, çiçek hastalığı, kolera, sıtma, İspanyol gribi gibi salgın hastalıklar da yer alır. Bu hastalıkların sembolik bir içerikleri yoktur. Çoğunlukla hayat ile edebiyat arasındaki gerçekçi ve dolaysız ilişkiden beslenirler. Olayın geçtiği dönemin toplumsal yapısıyla, şartlarıyla, hastalığın gelişim süreciyle yakından ilişkilidirler.

Hüseyin Rahmi Gürpınar'ın Hakka Sığındık (1919) isimli romanı İspanyol gribi çerçevesinde kurgulanır. İnsanlar arasındaki gelir adaletsizliğinin giderek arttığı, birçok insanın yoksulluk içerisinde kıvrandığ İstanbul'da Hacı Ferhat Efendi ile Hafız İshak Efendi'nin başından geçenler polisiye kurguyla anlatılır. Dünyayı kasıp kavurmakta olan İspanyol gribi zengin fakir demeden her haneden insanın ölümüne neden olur. Hafız İshak Efendi’nin on gün içinde önce torunu sonra da onun annesiyle babası vefat eder. Bu arada Hacı Ferhat Efendi ile Hafız İshak Efendi'nin konaklarına Abdal Veli imzalı mektuplar gelir. Kendisini ermiş kişi ve din büyüğü olarak tanıtan Abdal Veli, ilk mektubunda Hafız İshak Efendi'nin konağından ölecek üç kişiyi bilir. İkinci mektubunda ise Hacı Ferhat Efendi ile Hafız İshak Efendi kendisine 500'er lira göndermezse Hacı Ferhat Efendi'nin konağından İspanyol gribi nedeniyle iki ölümün olacağını söyler. Birinci mektuptaki bilgilerin doğru çıkması ve ailelerinden yeni insanların öleceğini öğrenen iki arkadaş Abdal Veli’ye parayı gönderirler. Ne var ki parayı götürenler soyularak geri dönerler. Bunun üzerine adli bir vaka halini alan olayın iç yüzü romanın sonunda anlaşılır. Nüzhet Ulvi isimli genç bir adam yangında anne babalarını, yoksulluk nedeniyle de kardeşlerini kaybetmiş iki çocuğa bakabilmek için İspanyol gribini bahane ederek Hacı Ferhat Efendi ile Hafız İshak Efendi'yi dolandırmıştır. ${ }^{30}$

Hakka Sığındık romanında işlenen İspanyol gribi toplumun farklı yönlerine $1 s ̧ 1 \mathrm{k}$ tutar. Bunlardan ilki, salgının ciddiyetini anlamayan bu nedenle de hastalığın yayılmasına ön ayak olan cahil insanlardır. "Hastalık, sağlık Allah’tan... Rabbimin takdiri ne ise o olur. Hekimler ne biliyormuş? Kelin medarı olsa kendi başına olur. Onlar ölmeyecek mi? Bu sene İspanyol'dan az hekim mi öldü? Ecele çare olmaz. O cahillere uyup da öyle söylemeyiniz. Rabbimin gücüne gider... Ona şirk koşmuş gibi olur' diyorlardı." ${ }^{\prime 1}$ Hastalığı Tanrı'nın takdiri olarak değerlendiren bu insanlar, hasta insanları ziyaret etmekten, onların eşyalarını kullanmaktan da çekinmezler. İkinci olaraksa romanda İspanyol gribinin, gelir adaletsizliğin giderek arttı̆̆ 1 bir dünyada zengin fakir ayırt etmeksizin insanların ölümüne neden olmasıdır. Romanın başında betimlenen mahallede, birçok ailenin günde tek ögün beslenebilmesi bile olanaksızken, Hacı Ferhat Efendi ile Hafız İshak Efendi'nin konaklarında her gün türlü yemekler pişirilir ve ziyafetler verilir. Bu adaletsizliğin devamı olarak ebeveynlerini kaybeden dokuz ve on bir yaşlarındaki iki çocuğun dilencilik ve fuhuş yaparak yaşamlarını sürdürmeye çalıştıklarından bahsedilir. Yani İspanyol gribi verem gibi, çoğunlukla konforsuz ortamlarda yaşayan, yetersiz beslenen insanlara değil maddi anlamda güç sahibi kişilere de bulaşır. Nüzhet Ulvi'nin Robin Hood gibi zenginden çalıp fakire vermesi ve İspanyol gribinin neden olduğu ölümler, yazarın bu adaletsizliği romantik bir bakış açısıyla giderme çabasıdır. Ayrıca bunu, kendini dini bütün olarak gören fakat hurafelerin, batıl inançların etkisinden

${ }^{30}$ Hüseyin Rahmi Gürpınar, Hakka Sığındık, ed. Emine Gürsoy Naskali, İstanbul: Ayrıntı Yayınları, 2018.

${ }^{31}$ Hüseyin Rahmi Gürpınar, Hakka Sığındık, s.20. 
kurtulamamış kahramanlar üzerinden işlemesinde de yergi vardır. Hakka Sı ı̆ındık romanında İspanyol gribi, toplumdaki aksaklıkları, cehaleti ortaya koymak için bir araç olarak kullanılmıştır. Bu nedenle gerçekçi bir tutumla işlenmiş ve dönemin anlayışını, koşullarını ortaya koyan bir arka plan olarak eserde yer almıştır.

Reşat Nuri Güntekin'in Salgın isimli uzun öyküsü 1935 yllında Perşembe dergisinde yayımlanmış, 2005 yılında da İnkılâp Yayınevi tarafından Madalyonun Ters Tarafı hikâyesi ile birlikte kitap olarak basılmıștır. Salgın, roman olmamasına rağmen hacimli bir eser olduğundan ve salgın altındaki koşullara yer verdiğinden bu çalışma kapsamında değerlendirilmesi uygun görülmüştür. Salgın, Gökpınar ilçesinin Karlıbel köyünde geçer. İlkokul öğretmeni Cevdet kaymakama yazdı̆̆ı mektubunda, köyde bir salgın hastalığın baş gösterdiğini, hastaların şiddetli baş ağrısı ve kusmanın ardından ateşler içinde, ağızlarından kan gelerek üç dört gün içinde öldügünü söyler. Öğretmen, ikinci olarak nahiye müdürüne gider. Çabalarının sonuç vermediğini gören Cevdet üçüncü olarak mutasarrıflığa yazar. Bu arada Karlıbel'e gönderilen doktorun zorlu kış şartlarından dolayı köye ulaşamaması nedeniyle Gökpınar’a Sağlık Müdürlüğünden müfettiş gönderilir. Öykünün sonunda olaya dâhil olan tüm bürokratlar fikir birliğiyle, köye gitmeden çevreden duydukları ayrıntılarla hastalık hakkında uydurma bir rapor hazırlarlar. Bu karışıklığın nedeninin asi, başına buyruk, düzen karşıtı davranışlarıyla bilinen öğretmen Cevdet olduğunu söylerler. Cevdet'e ihtar ve on beş gün maaş kesme cezası verirler. Fakat Cevdet'e aldığ 1 cezaları tebliğ eden zarf, öğretmenin bilinmeyen bir salgın hastalık nedeniyle öldüğü bilgisiyle Kaymakamlığa iade edilir. ${ }^{32}$

Salgın öyküsü, dünya tarihinde görülmüş, gerçek bir hastalıktan esinlenmez. Öyküde üzerinde durulan, salgının ışık tuttuğu aksaklıklardır. Hastalık hayalî olmasına rağmen ele alınış biçimi gerçekçidir. Köyde bulaşıcı bir hastalığın baş gösterdiğini fark edip Kaymakam'a mektup gönderen Cevdet şu satırları yazar: "Köylüler cahil insanlar, hastalıktan sakınmasını, korunmasını bilmiyorlar. 'Aman çoluk çocuğunuzu kollayın. Belki geçer' diyecek olursam kızıyorlar. 'Biz çok şükür Müslüman insanlarız. Hastadan iğrenmek günahtır' diyorlar." 33 Öyküden alınan bu k1sımda tıpkı Hakka Sığındık'ta olduğu gibi insanların salgının yayılmasında etkili oldukları, bunun, onların batıl inançlarından, dini yanlış yorumlamalarına dayanan tavırlarından kaynaklandığı görülür. Öyküde ikinci olarak ise bürokrasinin işleyişine yönelik bir eleştiri vardır. İdarî birimler arasındaki kopukluk, mektupların yöneticilerin eline geçmesinde yaşanan gecikmeler, yine yöneticilerin karar almaktaki beceriksizlikleri ve umursamazlıkları, ilçenin yalnızca bir doktoru olması gibi sorunlar salgın etrafında eleştirilir. Reşat Nuri'nin pek çok eserinde din / din görevlileri ve öğretmenler üzerinden yaptığı karşılaştırma bu eserde de görülür. Aklı, cesareti ve aydınlığı temsil eden ögretmen tiplemesinin suçlu ilan edilmesi fakat salgın hastalık nedeniyle öldüğünden kendisine cezalandırmaya dair bilginin ulaştırılamaması eseri trajikomik hale getirir. Böylelikle adı konulamayan hastalık aracllığıyla 1930'ların Anadolu'suna ve zihniyetine sşık tutulur.

\footnotetext{
${ }^{32}$ Reşat Nuri Güntekin, Salgın \& Madalyonun Ters Tarafi, İstanbul: İnkılâp Kitabevi, 2005, s.7-77.

${ }^{33}$ Reşat Nuri Güntekin, Salgın \& Madalyonun Ters Tarafi, s.11.
} 
Yaşar Kemal'in 1952'de yayımlanan Hüyükteki Nar A ̈̆acı adlı romanında ise sitmaya yer verilir. Romanda, tarladaki ekinleri kuruduğu ve yoksulluk çektikleri için Çukurova’ya ırgatlık yapmaya giden bir grup insanın öyküsü anlatılır. Beş kişiden oluşan grupta Yusuf sıtma hastasıdır. Daha önce çalışmak için gittiği Çukurova'da hastalanmıştır. "Sağ eliyle boyuna karnını gösteriyordu. Karnı gebe karıların karnı gibiydi. Boynu çöp gibi ince, kalın dudakları yarık yuruk, yüzünde kan eseri yoktu." ${ }^{34} \mathrm{Ne}$ var ki romanın başında arkadaşlarını Çukurova'ya gitmekten vazgeçirmeye çalışan Yusuf, daha sonra ekonomik kaygılarla arkadaşlarına katılır. İş bulamadan, karınları doğru dürüst doyuramadan zorlu şartlar altında yaptıkları bu yolculuk Yusuf için oldukça zahmetli olur. Sağlık durumu giderek kötüleşir, yürüyemez hale gelir. "Kimi her yanını ateş alıyor, baygın düşüyor, kimi üşüyordu yayla karı gibi. İki haftadan sonra gayrı yürüyemez oldu. Ekmek yemiyor, bol bol Çukurovanın ılık, kan gibi suyunu içiyordu. Bir deri bir kemik kaldı." ${ }^{35}$ Ayrıca iş bulma umuduyla Çukurova'yı baştan sona kateden grup yollarda sıtmadan hayatlarını kaybetmiş insanlara rastlarlar. "Yollarda kalmış ölüler gördüler. Bir akşamüstü karşılaştıkları ölünün üstünü yolun tozları örtmüştü. Tozların altındaki yüzü kehribar gibiydi. Bacaklarını germiş, ayaklarını dikmişti." ${ }^{36}$ Roman, kutsal kabul ettikleri nar ağacına ulaşmalarıyla sona erer. Hüyükteki Nar Ağaci'nda sıtma aracılığıyla insanların çaresizliği, geçinmek, hayatta kalabilmek uğruna neleri göze aldıkları, eserin geçtiği coğrafyanın özellikleri konu edilir. Yaşar Kemal'in romanında salgın hastalık toplumsal sorunlara 1şık tutmak için kullanılan bir temadır. Yusuf un hasta olmasına rağmen çalışmak istemesi, yollarda kalan ölüler, traktörlerin tarımda kullanılmaya başlamasıyla işçilerin iş bulamaması gibi sorunlar hem sistemi betimler hem de eleştirir.

2020 yılından beri devam etmekte olan COVİD-19'u işleyen edebiyat eserlerinin sayısının zamanla artacağı muhakkaktır. Mehmet Eroğlu'nun 2021 yılında çıkan son romanı Meraklı Adamın On Günü'nde ise hastalığa dönemin koşullarını, insanların tavırlarını anlatırken yer verilmiştir. Roman, birinci kitabı Kötü Adamın On Günü (2019), ikinci kitabı İyi Adamın On Günü (2020) olan polisiye serinin son kitabıdır. Romanda eski bir avukat olan Sadık Demir'in TikTok fenomeni genç bir kadının kayboluşunu araştırırken başından geçenler anlatılır. Korona salgının ilk günlerinde yaşanan maske bulma sıkıntısından, insanların marketlere hücum etmesinden bahseder. Apartman görevlisi, Sadık'a piyasada bulamayacağını söyleyerek tanesi beş liradan maskeye satmaya çalışır. Eczanelerde kolonya ve dezenfektan da kalmadığını söyleyerek maske alması için onu ikna etmek ister, bir lira indirim yaparak maskeyi Sadık'a satar. ${ }^{37}$ İnsanlar tıpkı Hüyükteki Nar Ağaci'nda olduğu gibi geçinebilmek uğruna canlarını tehlikeye atarlar. "Virüse asıl aldırmayan kalabalık PTT şubesinin önünde. (...) İzdiham sıranın başında. Virüs nedeniyle ihtiyaç sahiplerine dağıtılacağı söylenen bin liranın peşine düşen yoksullar, gözyaşlarına aldırmadan birbirlerini eziyorlar. Sosyal mesafenin ruhuna Fatiha." ${ }^{8}$ Salgın, insanların parasız kalacakları konusunda endişeye kapılmasına neden olmuştur.

\footnotetext{
${ }^{34}$ Yaşar Kemal, Hüyükteki Nar A ̆gacı, İstanbul: YKY Yayınları, 2020, s.10.

${ }^{35}$ Yaşar Kemal, Hüyükteki Nar Ağacı, s.38.

${ }^{36}$ Yaşar Kemal, Hüyükteki Nar A ̆gacı, s.37.

${ }^{37}$ Mehmet Eroğlu, Meraklı Adamın On Günü, İletişim Yayınları, s.13.

${ }^{38}$ Mehmet Eroğlu, Meraklı Adamın On Günü, s.33.
} 
Bu nedenle de insanlar hastalanmaktan çekinmeyerek yardım sırasında birbirlerini ezerler. Hastalıkla beraber, insanlar yaşamlarını sürdürmelerinin temel gereklerinden olan beslenmenin tehdit altında olduğunu sezmişler ve yiyecek depolamaya başlamışlardır. Sadık bunu şu sözlerle ifade eder: "Gerçekten de market, kapıdaki adamın dediği gibi dolu, girince görüyoruz. Öyle anlaşılıyor ki insanlar salgınlarda fazla yiyip içiyor. Tabii buna istifçilik damarlarının kabarmasını da eklemek gerek..." 39 Aslında bu durum insanın tehlike altında yaşamını sürdürme çabasıdır. Meraklı Adamın On Günü'nde olay örgüsünü şekillendiren polisiye kurgunun özellikleri olan suç, suçlu ve gizemdir, romanın ana teması korona değildir. Fakat olay 2020 yılında geçtiği için yazar, toplumun gündeminden beslenir. Sokakları betimlerken, dükkânların önünden geçerken, karakterleri tanıtırken koronanın yaşamımızdaki etkilerini göz ardı etmez. Aslında bu tutum bölümün başında vurgulandığı üzere günlük yaşamla edebiyatın kurduğu gerçekçi ilişkiye dayanır.

Tanzimat'tan bu yana Türk romanında görülen salgın hastalıklardan verem dışında olanlar, eleştirel bir tavırla dönemin şartlarını, insanların anlayışlarını, sistemi değerlendirirler. Bu eserlerde ele alınan salgın, çoğunlukla olayların içindeki bir unsur veya romanın fonudur. Salgın aracılığıyla yöneticilerin tutumları, insanların cahilliği, ekonomik sıkıntılar konu edilir. Yaşar Kemal'in ve Mehmet Eroğlu'nun romanlarındaki ortak tavır ise şudur: İnsan, ölümcül bir hastalıkla karşı karşıya olsa dahi geçinme endişesi hastalığa yakalanma ihtimalini görmezden gelmesine neden olur. Çünkü Doğu kültüründe teslimiyet ve kabullenme vardır, hastalık yaşamı sona erdirmek için sadece bir araçtır. Oysa insanın hayatta olduğu sürece geçinebilmesi için para kazanması gerekir. Buna bir de zorlu ekonomik koşullar eklendiğinde kişi hayati tehlikesini ikinci plana atar. Ayrıca Reşat Nuri'nin Salgın öyküsüyle Hüseyin Rahmi’nin Hakka Sığındık romanında insanların salgın tehlikesini dikkate almamasına din kaynaklı bir açıklama getirilir. Her iki eserde de insanlar, ecelin Allah'tan olduğunu ve hastaya yardımcı olmanın Müslüman kişinin görevlerinden olduğunu söyleyerek hasta insanlarla bir arada olmaktan, onları ziyaret etmekten çekinmezler. Verem ise sıtma, İspanyol gribi, korona gibi hastalıkların aksine yaşamın trajedilerinden beslenir. İyi beslenemediği, fiziksel imkânların yetersiz olduğu yerlerde yaşadığ 1 için vereme yakalanan bireylerin yoksullukları anlatılardaki dram unsurunu güçlendirir. Verem, kişinin ciğerlerindeki enfeksiyona, imkânlarının yetersizliğine değil çaresizliğine, ümitsizliğine, ayrılık acısına, karşılıksız aşkına veya sanatçı ruhuna işaret eder.

\section{Distopik ve Fantastik Unsurlar Bağlamında Salgın Hastalıklar}

Türk edebiyatındaki salgın hastalık teması 2000’lerden sonra yeni bir görünüm kazanır. Artık toplumcu eleştirinin aracı olmaktan çıkarak ve edebiyatın gerçeklikle kurduğu, betimlemeye, tespit etmeye dayanan ilişkiden sıyrılarak yeni gerçekliğin inşasında söz sahibi olur. Bu gerçekliğin temelinde distopik ve fantastik unsurlar vardır. Yeni dünya düzeni kaosun ve yıkımın ardından kurulur. Salgın hastalıkların şekillendirdiği yeni dünya, insanları otoriter, karamsar ve kötücül bir gerçeklikle karşı karşıya getirir. Bu dünya yer yer hayal mi gerçek mi olduğu ayırt edilemeyen, insan aklını şüpheye düşüren unsurlarla çevrilidir.

\footnotetext{
${ }^{39}$ Mehmet Eroğlu, Meraklı Adamın On Günü, s.40-41.
} 
Şebnem Şenyer'in 2008 yılında yayımlanan 30 Şubat Bir Gülme Salgının Romanı isimli eserinde şehri etkisi altına alan ve şubat ayı boyunca devam eden gülme salgını konu edilir. Hastalığa yakalanan insanların birçoğu gülerken nefessiz kalarak, damarları yırtılarak, kalp krizi geçirerek ölürler. Üstelik salgına yakalanan insanlar, sağlıklı insanları gıdıklayarak hastalığı bulaştırırlar. Salgını durduran tek şey insanların rüya görmesidir. Romanın sonunda rüya makinesinin icadıyla hastalık sona erer. ${ }^{40}$ Şebnem Şenyer'in eseri çeşitli fantastik unsurlarla örülmüştür. Gülmenin bulaşıcı bir hastalığa dönüşmesi, rüya makinesinin icadı, ana kahraman Afsane Sahavet'in kardeşi Onan'ın takvimcilik denilen meslekle geçimini sağlaması, Afsane'nin kızının rüya görmeme hastalığına yakalanması ve bu konuda tedavi görmesi romanı fantastik yapan niteliklerdir. Özlük'ün fantastik tanımına uygun olarak gerçek dünyanın içinde gerçeküstü unsurlara yer vererek okuyucuyu şaşırtıp kararsız bırakırlar. ${ }^{41}$ Romanda karantinalar, şehrin giriş çıkışlarının kapatılması, insanların gülmeden etkilenmemeleri için maskeyle yüzlerini kapatması gibi bulaşıcı hastalıkların gerçeklerinden de bahsedilir.

Afşin Kum'un Sıcak Kafası'nda (2016), Cem Akaş'ın Y’sinde (2018), Onur Gürleyen'in Hastalık'ında (2018) ise salgın hastalıklar sonucu ortaya çıkan distopik dünyalar anlatılır. Sicak Kafa'da ARDS'in (Acquired Reasoning Deficiency Syndrome / Edinilmiş Akıl Yürütme Yoksunluğu Sendromu) yayıldığı bir dünya anlatılır. Hastalığa yakalanarak anlamsız ifadelerle konuşmaya "abuklama" adı verilir. Hastalığın bulaşması için yaklaşık altı dakika abuklayan birisiyle konuşmanız yeterlidir. Bu nedenle bütün dünyada karantina bölgeleri oluşturulur. Televizyon ve internet hizmetleri durdurulur. Çünkü sağlıklı insanların abuklayan kişinin görüntülerini izlemesi de hastalığın bulaşmasına neden olur. İnsanlar evlerinin dışında mümkün olduğunca az insanla muhatap olmaya çalışırlar. Romanda hastalığa yakalanıp kendini iyileştirmeyi başaran fakat tedaviye ait belgeler yangında kaybolduğu için tedavinin yöntemlerini hatırlamayan dilbilimci Murat Siyavuş'un başından geçenler anlatılır. Roman, SMK'da (Salgın Önleme Merkezi) hastalığa karşı tedavi geliştirmeye çalışan Murat Siyavuş'un ikinci kez hastalığa yakalanmasıyla sona erer. ${ }^{42} Y$ isimli romanda, yıllar önce yaşanan bir salgından sonra kadınların erkek çocuk doğuramadığı, doğan erkek çocukların da öldüğü, bu nedenle sadece kadınların kaldığı bir dünya anlatılır. Yeni dünyada erkeklik artık tehlikeli ve zararlı bir hastalık olarak kabul edilir. Roman, Arendi ve İliada isimli iki kadının yaşadıkları evin önüne sepette erkek bir bebek bırakılmasıyla başlar. Çift, Constantine adını verdikleri bu bebeği kadın olarak yetiştirir ve erkek olduğunu herkesten saklarlar. Roman, bu çiftin ve Constantine'nin başından geçenleri anlatır. $Y$ romanında salgın, dünyayı şekillendiren tarihi bir gerçeklik olarak işlenir. Bu nedenle salgın sırasında inanların yaşamı değil, onun ardından oluşan yeni dünya düzeni anlatılır. ${ }^{43}$ Onur Gürleyen'in Hastalık isimli romanında ise, aniden şehrin bir yakasında ortaya çıkan, insanların vücutlarında mor, yeşil izlerle, kızarıklarla kendini belli eden, onların acılar içerisinde kıvranmasına neden olan bir salgından bahsedilir. Salgın zaman içerisinde şehrin her iki yakasında da görülür. Fakat salgının ilk

\footnotetext{
${ }^{40}$ Şebnem Şenyer, 30 Şubat Bir Gülme Salgının Romanı, İstanbul: Can Yayınları, 2008.

${ }^{41}$ Nuran Özlük, Türk Edebiyatında Fantastik Roman, İstanbul: Hiperlink Yayınları, s.28.

${ }^{42}$ Afşin Kum, Sıcak Kafa, İstanbul: April Yayınları, 2016.

${ }^{43}$ Cem Akaş, $Y$, İstanbul: Can Yayınları, 2018.
} 
ortaya çıktığı yer karantina bölgesi kabul edilir. Hasta olanlar oraya gönderilir, oradan kimsenin çıkmasına izin verilmez. Zamanla hastalığa yakalananların yaşamlarını devam ettirdikleri görülür. Ne var ki ciltleri yeşil bir renk almakta, çok zayıfladıkları için vücutlarındaki mavi damarlar seçilmekte, tırnakları, dişleri ve kulakları sivrilip uzamaktadır. Hastalık ölümcül olmaktan çıkınca şehrin iki yakası arasında savaş başlar. Çoğunlukla sağlıklı insanlardan oluşan taraf savaşta yenilir, insanlar yiyecek, barınma gibi temel ihtiyaçlarını dahi karşılayamaz hale gelirler. Birçok yerde çalışma kampları kurulur. ${ }^{44}$

Sıcak Kafa, Y, Hastalık romanlarının ortak özelliği distopik unsurlardır. Distopya sözcügü hastalıklı, kötü, kusurlu, sakıncalı yer anlamlarındaki "dus" ve "topos" sözcüklerinin bir araya getirilmesiyle oluşmuştur. ${ }^{45}$ Edebiyatta ise kaosun ve yıkımın ardından kurulan yeni düzene işaret eder. Kaba tabiriyle ütopyanın tersi özellikler gösteren bir dünyayı anlatır. Bu dünyada, insanların temel ihtiyaçlarını gidermekte sıkıntı yaşamaları, bu nedenle ilkel yöntemlerle ihtiyaçlarını gidermeye çalışmaları, manevî duygu ve davranışlardan uzaklaşmaları gibi özellikler görülebilir. Fakat bu romanların en tipik özellikleri baskıcı, otoriter, denetleyen ve gözetleyen yönetimlerin iş başına geçmesidir. Salgının kontrol altında tutulmak istemesiyle alınan yeni önlemler bir süre sonra toplumların yaşam biçimi haline gelir. Hastalığın bulaşmasını engellemek için kurulan karantina bölgeleri sosyal sınıf göstergelerine dönüşür. Sıcak Kafa'da insanların refah içerisinde yaşadığ Salgın Kontrol Merkezi, Hastalık'ta sağlıklı insanların yaşadığı şehrin bir yakası buna örnek olarak verilebilir. Hastalık romanında insanların karınlarını doyurmak için çalışma kamplarında çalışmaya mecbur bırakılmaları, $Y$ romanında devletin erkeklerin takibini yapabilmek adına insanların seyahat, hastalık geçmişi, eğitim hayatı, iş olanakları, kültür sanat ürünlerinin dağıtımı gibi günlük yaşam kapsamındaki pek çok ayrıntıda söz sahibi olması otoriter yönetim mekanizmasının örneklerindendir. Korona önlemleri kapsamında gündeme gelen HES kodları, Çin'in karantina önlemleri kapsamında binalara, metro girişlerine ve tren istasyonlarına yerleştirdiği kameralar henüz bir edebiyat eserine konu olmasalar da benzer bir bakış açısıyla değerlendirilebilir. Peki 2000'lerden sonra kaleme alınan edebiyat eserlerinde salgın teması neden dönüşüme uğramıştır?

Distopik eserlerin çoğunda görülen gözetlemenin temeli modernizmin tekçi, mutlakçı ve hiyerarşik yapısına dayanır. Bu yapı 80'lere kadar devletin koyduğu yaptırımlar, idareciler, kolluk güçleri aracılığıyla baskıcı biçimde sağlanırken dijital çağın giderek yükselişe geçmesiyle gözetlemenin biçimi de değişir. Okmeydan'a göre günümüzde insanlar haz ve eğlence fikriyle artık görünür olmayı kanıksamışlardır. Yani modernist dönemde zorlamaya dayalı gözetim yerini gönüllü gözetime bırakmıştır. ${ }^{46}$ Seyahat edebilmek, insanların toplu halde bulunduğu binalara girmek için kullanılması mecburi olan sağlı uygulamaları, bilgisayar ve cep telefonu kullanımı, kamera kayıtları insanları günlük yaşamlarını sürdürebilmek adına gözetleme karşısında umursamaz yapmıştır. Bu duruma, modernizmin sistem ve düzen

${ }^{44}$ Onur Gürleyen, Hastalık, İstanbul: NotaBene Yayınları, 2018.

${ }^{45}$ Gregory Claeys, Ütopya Edebiyatı, çev. Zeynep Demirsü, İstanbul: Türkiye İş Bankası Kültür Yayınları, 2018, s.4.

${ }^{46}$ Sefa Bitirim Okmeydan, "Postmodern Kültürde Gözetim Toplumunun Dönüşümü: 'Panoptikon'dan 'Sinoptikon' ve 'Omniptikon'a”, AJIT-e: Online Academic Journal of Information Technology, 8/30 (2017), s.47. 
önceliğine zit şekilde postmodernizmin öne sürdügü kaos ve anarşi de eklenince distopik edebiyatın unsurları tamamlanmış olur. Ayrıca postmodernizm, modernizmin öncelediği akılcılığa tepki olarak hayalî, olağanüstü anlatılara, büyü, efsane, mit gibi akıldışı unsurlara yer verir. Bu unsurların varlığı fantastik metinlerin gelişimine zemin hazırlar. Böylelikle yakın tarihli salgının işlendiği metinler, modernizm ve postmodernizmin etkisiyle distopik ve fantastik özellikler gösterir. Çünkü insanın artık yaşamı, insanları ve kendisini kavrama, yorumlama biçimi değişmiştir. Önemli olan hastalığın kendisi ve tedavisi değil, hastalık fikri etrafında insanlığın ve dünyanın geçirdiği dönüşümdür. Bu nedenle distopik/fantastik unsurlar bağlamlarında değerlendirilen dört romanda da olay hayalî hastalıklar etrafında kurgulanir.

\section{Sonuç}

Salgın hastalıkların geçmişi insanlığın ortaya çıkışına dek götürülebilir. Bu uzun süreçte hastalıkların edebiyatla kurduğu ilişki de çok yönlüdür. Modern Türk romanında bu ilişkinin seyri hakkında fikir sahibi olabilmek adına bu çalışmada Felâtun Bey ile Râkım Efendi, Taaşşuk-ı Talât ve Fitnat, Aşk-ı Memnu, Hakka Sığındık, Yeşil Gece, Salgın, Hüyükteki Nar Ağacı, 30 Şubat Bir Gülme Salgının Romanı, Sıcak Kafa, Y, Hastalık, Meraklı Adamın On Günü isimli eserlerden örnekler verilmiş, otuz bir romandaki hastalıkların ise dökümü yapılmıştır.

19. yüzyılda Türk edebiyatında da dünya edebiyatlarında olduğu gibi verem, salgın hastalık temasının ilk sıralarında yer alır. Yazar ve şairler veremin yarattığı kaygıdan değil, trajedisinden, sembolik anlamlarından beslenir. II. Meşrutiyet Devri'nde, cumhuriyetin ilk yıllarında verem romanlarda görülmeye devam etse de olay örgüsü ve karakter yaratımı üzerindeki etkisi giderek azalır. Veremle birlikte romanlarda işlenmeye başlanan diğer salgın hastalıklar ise özellikle cumhuriyetin ilanından sonra toplumcu gerçekçi bir bakış açısıyla ele alınmaya başlar. Bunda, Anadolu merkezli eğitim ve aydınlanma hareketinin başlamasının da etkisi vardır. Böylelikle salgın hastalıklar yöneticilerin beceriksizliğini, idarî birimlerdeki aksaklıkları, gelir adaletsizliğini, yoksulluğu, cehaleti anlatmak için birer tema haline gelirler.

2000'li yıllara gelindiğinde postmodernizmin etkisiyle hayalî salgın teması etrafinda, distopik ve fantastik anlatılar ortaya çıkar. Bu eserlerde salgın, kaos ve y1kıma neden olduktan sonra yeni bir dünya düzeninin doğmasına neden olur. $\mathrm{Bu}$ dünya düzeni, devletin salgını kontrol etme amacıyla koyduğu kuralların kalıcı ve daha katı hale geldiği, insanların temel ihtiyaçlarını gidermekte sıkıntı yaşadığı, sosyal sınıflar arasındaki uçurumların arttığı bir yaşamı destekler.

Dönem fark etmeksizin incelenen romanların çoğunda hastalığı ciddiye almayan ve çeşitli nedenlerle izolasyonu önemsemeyen insanlardan oluşan bir grup yer alır. Distopik anlatılarda ise anarşinin hüküm sürdügü bir ortamda insanların beslenme ve barınma ihtiyaçlarını gidermek için yasadışı yollara ve şiddete başvurdukları görülür. Türk edebiyatında, tarihte görülen salgınların işlendiği romanların hiçbirinde ülke veya şehir düzeyinde bir karantinadan bahsedilmemiştir. İn- 
sanlar, hijyen ve sosyal mesafe kurallarına uygun biçimde yaşamlarına devam etmişlerdir. Şehir ve ülke sınırlarının kapatılmasına, karantina bölgelerinin oluşturulmasına yalnızca distopik/fantastik anlatılarda yer verilir. 2020 yılından beri devam eden süreçte görülmüştür ki insanlık kendisini fantastik olarak değerlendirdiği yeni bir gerçekliğin içinde bulmuştur. İnsanlığın son aylarda karşı karşıya kaldığ 1 gelişmelerin bu denli sarsıcı olmasının ardında yatan nedenlerden biri de kurgulanan kaosun günlük yaşamın gerçekliği halini almasıdır.

\section{Kaynakça}

Ahmet Mithat Efendi. Felâtun Bey ile Râkım Efendi. Haz. Mehmet Emin Agar. İstanbul: Enderun Kitabevi, 1994.

Akaş, Cem. Y, İstanbul: Can Yayınları, 2018.

Akça, Fatih. "Çağdaş Bir Kış Masalı: Tipi”. Roman Kahramanları (Salgın Edebiyatı Dosyas1). 44 (2020): 127-130.

Asiltürk, Bâki. Reşat Nuri Güntekin'in Romanlarında Hastalık. İstanbul: İkarus Yayınları, 2009.

Bulut, Faik, "Salgın ve Hastalıkların Edebiyat ve Sanata Yansımış Hikayeleri". Indepent Türkçe. Erişim 26 Ocak, 2021.

https://www.indyturk.com/node/162101/türkiyeden-sesler/salgin-

hastalıkların-edebiyat-ve-sanata-yansımış-hikayeleri.

Claeys, Gregory. Ütopya Edebiyatı. Çev., Zeynep Demirsü. İstanbul: Türkiye İş Bankası Kültür Yayınları, 2018.

Çeçen, Namık. “1933'ten Günümüze Lise Tarih Ders Kitaplarında Salgın Hastalıkların İşlenişine Genel Bir Bakış". Milli Eğitim. 1 (2020): 919-946.

Çıkla, Selçuk. Edebiyat ve Hastalık. İstanbul: Kapı Yayınları, 2016.

Demir, Eda. "Philip Roth'un Nemesis'inde Ayarı Bozuk Terazi ve İlahi Adalet". Roman Kahramanları (Salgın Edebiyatı Dosyası). 44 (2020): 131-135.

Doğru, İsmail Cem. "Shelley'nin Kapanış Teorisi: Son İnsan”. Roman Kahramanları (Salgın Edebiyatı Dosyası). 44 (2020): 19-26.

Domini, John. "Uyduruk Haberler, Aşırı Vatanseverlik ve Savaş: 1918'de Amerika". Çev., Altay Ömer Erdoğan. Roman Kahramanları (Salgın Edebiyatı Dosyasi). 44 (2020): 56-62.

Erdemir, Firdevs, Gülzade Uysal, Ahu Çırlak ve Arzu Akman. "Yeni ve Yeniden Tanımlanan Enfeksiyonlar ve Enfeksiyon Kontrolü II 21. Yüzyılda Yeniden Tanımlanan Enfeksiyonlar ve Enfeksiyon Kontrolü”. Ege Üniversitesi Hemşirelik Yüksek Okulu Dergisi. 27/1 (2020): 61-75.

Erdoğan, Altay Ömer. "Korkunç Şeylerin Masumiyeti”. Roman Kahramanları (Salgın Edebiyatı Dosyası). 44 (2020): 145-151.

Erk Görgülü, Hüma. “Cehennem: Şimdi Değilse, Ne Zaman?”. Roman Kahramanları (Salgın Edebiyatı Dosyası). 44 (2020): 136-140.

Eroğlu, Mehmet. Meraklı Adamın On Günü. İstanbul: İletişim Yayınları.

Güntekin, Reşat Nuri. Salgın \& Madalyonun Ters Tarafı. İstanbul: İnkılâp Kitabevi, 2005.

Güntekin, Reşat Nuri. Yeşil Gece. İstanbul: İnkılâp Yayınları, 2017. 
Gürleyen, Onur. Hastalık. İstanbul: NotaBene Yayınları, 2018.

Gürpınar, Hüseyin Rahmi. Hakka Siğındık. Haz., Emine Gürsoy Naskali. İstanbul: Ayrıntı Yayınları, 2018.

Kalkan, Melike Selcan. “19. Yüzyıl Türk Edebiyatında Verem Hastalığı”, Yüksek Lisans Tezi, Marmara Üniversitesi, 2017.

Kara, Esra. "Toplumsal Bir Olgu Olarak Sanat ve Edebiyat (Küçük Bir Sanatçının Omuzlarında Koca Bir Evren)”. Hece (Hayat Edebiyat Siyaset Özel Sayısı). 90/91/92 (2004): 138-139.

Karakiraz, Erkan. “Edgar Allen Poe’nun Maskesi - Kızıl Ölümün Maskesi Üzerine”. Roman Kahramanları (Salgın Edebiyatı Dosyası). 44 (2020): 32-34.

Kemal, Yaşar. Hüyükteki Nar A ğacı. İstanbul: YKY Yayınları, 2020.

Kum, Afşin. Sıcak Kafa. İstanbul: April Yayınları, 2016.

Okmeydan, Sefa Bitirim. "Postmodern Kültürde Gözetim Toplumunun Dönüşümü: 'Panoptikon'dan 'Sinoptikon' ve 'Omniptikon'a”. AJIT-e: Online Academic Journal of Information Technology. 8/30 (2017): 45-69.

Özlük, Nuran. Türk Edebiyatında Fantastik Roman. İstanbul: Hiperlink Yayınları, 2011.

Parıldar, Hülya. “Tarihte Bulaşıcı Hastalık Salgınları”. Tepecik Eğitim ve Araştırma Hastanesi Dergisi. 30 (2020): 19-26.

Sontag, Susan. Metafor Olarak Hastalık Aids ve Metaforları. Çev., Osman Akınhay. İstanbul: Can Yayınları, 2020.

Şemsettin Sami. Taaşşuk-ı Talât ve Fitnat. Haz., Özlem Nemutlu. İstanbul: Özgür Yayınları, 2015.

Şenyer, Şebnem. 30 Şubat Bir Gülme Salgının Romanı. İstanbul: Can Yayınları, 2008.

Uğurlu, Yavuz Selim. “Türk Romanında Verem Üzerine Bir İnceleme”. Sosyal Bilimler Enstitüsü Dergisi. 15 (2020): 57-69.

Uraldı, Cem. "Edebiyat ve Sağlık”. Hece (Edebiyat ve Hastalık Dosyası). 225 (2015): 101-102.

Uşaklıgil, Halit Ziya. Aşk-ı Memnu. Haz., Muharrem Kaya. İstanbul: Özgür Yayınları, 2015.

Yalçın Çelik, Sıddıka Dilek. "Orhan Kemal'in Hikayelerinde İnce Hastalık: Verem ve Veremliler”. Doğumunun Yüzüncü Yılında Orhan Kemal Sempozyumu Kitabı. Ankara: Atatürk Kültür Merkezi Yayınları, 2016.

Yalman, Neslihan. “Koronovirüsten Öncesi - Romandan Güne Bakmak 'Salgın' Notları: İzmir, Türkiye 1 Haziran 2020”. Roman Kahramanları (Salgın Edebiyatı Dosyas1). 44 (2020): 93-100.

Yenen, Zeynep. “Trump ve Bolsonaro Manzoni Okusaydı”. Roman Kahramanları (Salgin Edebiyatı Dosyası). 44 (2020): 27-31.

Yılmaz, Medeni. "Venedik'te Ölüm: Şimdi Ben Gidiyorum, Phaidros, Sen Burada Kal!”. Roman Kahramanları (Salgın Edebiyatı Dosyası). 44 (2020): 35-40. 


\title{
Epidemic Diseases in Turkish Novel
}

\author{
HAYRUNISA TOPÇU* \\ nisa@hacettepe.edu.tr \\ ORCID ID: 0000-0003-2624-5148
}

\begin{abstract}
The history of epidemics is as old as the emergence of humanity. Mass deaths, desperation and suffering become a rich source of material in terms of literature. In this study called Epidemic Diseases within Turkish Novel, works that have been about epidemic diseases in novels since Tanzimat have been tried to be identified. Among these works, in chronological order Felâtun Bey ile Râkım Efendi, Taaşşuk-ı Talât ve Fitnat, Aşk-ı Memnu, Hakka Siğındık, Yeșil Gece, Salgın, Hüyükteki Nar Ağacı, 30 Şubat Bir Gülme Salgının Romanı, Sicak Kafa, Y, Hastalı, Meraklı Adamın On Günü have been selected for evaluation. The purpose of evaluation these novels is to observe the shift in the epidemic theme in novels. As a matter of fact while tuberculosis disease stands out in the novels of Tanzimat and Servet-i Fünû; the epidemic becomes a tool in referring to social problems in the novels of the Second Constitutional and Republic Period. In novels written in 2000s, the epidemic theme is shaped around dystopian / fantastic elements.
\end{abstract}

Keywords: Disease, Epidemics, Turkish novel, Fantastic novel, Dystopian novel

* Dr. Lect., Hacettepe University, Faculty of Letters, Department of Turkish Language and Literature. 